Міністерство освіти і науки України

Національний університет «Острозька академія» (Острог, Україна)

ДВНЗ «Київський національний економічний університет імені Вадима Гетьмана» (Київ, Україна)

Університет державної фіскальної служби України (Ірпінь, Україна)

Запорізький національний університет (Запоріжжя, Україна)

Поліський державний університет (Пінськ, Республіка Білорусь)

Вища школа бізнесу та підприємництва

(Островець Свентокшиський, Польща)

Люблінська політехніка (Люблін, Польща)

Збірник наукових тез

\title{
ФІНАНСОВА СИСТЕМА КРАЇНИ: ТЕНДЕНЦІЇ ТА ПЕРСПЕКТИВИ РОЗВИТКУ
}

\author{
МАТЕРІАЛИ VІІІ МІЖНАРОДНОЇ \\ НАУКОВО-ПРАКТИЧНОЇ ІНТЕРНЕТ-КОНФЕРЕНЦІЇ
}

22 жовтня 2021 p.

Острог

Видавництво Національного університету «Острозька академія» 2021 
УДК 336

ББК 65.26

$\Phi 59$

Друкується за ухвалою ради економічного факультету

Національного університету «Острозька академія»

(протокол № 3 від 26 жовтня 2021 року)

\section{Редакційна колегія:}

Шевчук Д. М., проректор з науково-педагогічної роботи Національного університету «Острозька академія», доктор філософських наук, професор;

Новоселецький О. М., декан економічного факультету Національного університету «Острозька академія», кандидат економічних наук, доцент;

Дем'янчук О. І., заступник декана економічного факультету з навчально-наукової роботи Національного університету «Острозька академія», доктор економічних наук, доцент;

Мамонтова Н. А., завідувач кафедри фінансів, обліку і аудиту Національного університету «Острозька академія», доктор економічних наук, професор;

Козак Л. В., завідувач кафедри економічної теорії, менеджменту і маркетингу Національного університету «Острозька академія», доктор економічних наук, доцент;

Кривицька О. Р., завідувач кафедри економіко-математичного моделювання та інформаційних технологій Національного університету «Острозька академія», доктор економічних наук, професор.

Фінансова система країни: тенденції та перспективи розвитку : матеріали VIII Міжнар. наук.-практ. інт.-конф. (м. Острог, 22 жовт. 2021 р.). Острог : Видавництво Національного університету «Острозька академія», 2021. 190 с.

DOI $10.25264 / 26.10 .2021$

УДК 336

ББК 65.26

Редакція не несе відповідальності за зміст тез.

(C) Автори статей, 2021

(C) Видавництво Національного університету «Острозька академія», 2021 


\section{MICT}

\section{Lyudmyla Alekseyenko, Oksana Tulai}

PECULIARITIES OF FINANCIAL AND CREDIT RELATIONS

IN THE CONTEXT OF DIGITAL TRANSFORMATION

OF FINANCIAL SERVICES

O. P. Антонюк

РОЗВИТОК ЗВІТНОСТІ ЗІ СТАЛОГО РОЗВИТКУ В КОНТЕКСТІ ДІЯЛЬНОСТІ АУДИТОРСЬКИХ ФІРМ

O. M. Apmox

ВИКОРИСТАННЯ ЛОГІСТИЧНОЇ РЕГРЕСІЇ ДЛЯ КРЕДИТНОГО

СКОРИНГУ ПОЗИЧАЛЬНИКІВ БАНКІВ

О. Бреславська

ІНФОРМАТИЗАЦІЯ БАНКІВСЬКОГО БІЗНЕСУ ЯК ЧИННИК РОЗВИТКУ ЕКОНОМІКИ

Н. М. Вдовенко

ОРГАНІЗАЦІЙНО-ЕКОНОМІЧНІ ПІДХОДИ ДО РОЗВИТКУ

СЕКТОРІВ РИБАЛЬСТВА ТА АКВАКУЛЬТУРИ У ПРОЦЕСІ

ВИРІШЕННЯ ГЛОБАЛЬНИХ ПРОБЛЕМ

А. О. Главацька

ОРГАНІЗАЦІЯ АУДИТУ ЗОБОВ' ЯЗАНЬ ПІДПРИЄМСТВА

О. І. Дем'янчук

ФІНАНСОВІ АСПЕКТИ ПЕНСІЙНОГО ЗАБЕЗПЕЧЕННЯ

В УКРАЇНI

М. П. Денисенко, А. О. Голотко

ОСНОВНІ ІНСТРУМЕНТИ КОНКУРЕНЦІЇ

Pawet Dziekański, Magdalena Wrońska

FINANCIAL INDEPENDENCE OF COUNTIES IN POLAND OVER THE YEARS 2007-2019

А. Д. Дмитрієва

СТАН ТА ПЕРСПЕКТИВИ РОЗВИТКУ МЕНЕДЖМЕНТУ

В УКРАЇНІ

А. О. Драгун

ТЕНДЕНЦІЇ ЗРОСТАННЯ ДОДАНОЇ ВАРТОСТІ В ГАЛУЗІ

ВИРОБНИЦТВА ХАРЧОВИХ ПРОДУКТІВ

О. А. Дубровик

ОЦІНКА ЯКОСТІ СКОРИНГОВИХ МОДЕЛЕЙ НА ОСНОВІ КРИТЕРІЇВ МАТРИЦІ СПРЯЖЕНОСТІ

M. O. Жumap

ІНСТРУМЕНТИ ФУНКЦІОНУВАННЯ ФІНАНСОВОЇ АРХІТЕКТУРИ ЕКОНОМІКИ УКРАЇНИ 


\section{К. О. Івтушок}

ФІСКАЛЬНЕ ЗНАЧЕННЯ НЕПРЯМОГО ОПОДАТКУВАННЯ 58

Г. Ю. Кернична, Л. В. Юрчишена

ФІСКАЛЬНА ЗНАЧИМІСТЬ НЕПРЯМОГО ОПОДАТКУВАННЯ

У ДОХОДАХ ДЕРЖАВНОГО І МІСЦЕВИХ

БЮДЖЕТІВ УКРАЇНИ

М. В. Кічурчак

НАУКОВІ ПІДХОДИ ДО ОЦНЮВАННЯ БЮДЖЕТНОГО

ФІНАНСУВАННЯ СФЕРИ КУЛЬТУРИ УКРАЇНИ

НА СУБНАЦІОНАЛЬНОМУ РІВНІ В КОНТЕКСТІ СТАЛОГО РОЗВИТКУ

\section{Л. В. Козак, І. І. Бровді}

ЕКОНОМІЧНІ ІМПЕРАТИВИ РОЗВИТКУ ЕКСПОРТНОГО

ПОТЕНЦІАЛУ АПК УКРАЇНИ

О. Ф. Корницька

ФІНАНСОВИЙ КОНТРОЛЬ - ГАРАНТІЯ УСПІШНОГО ГОСПОДАРЮВАННЯ

\section{T. С. Корнійчук}

ОСОБЛИВОСТІ ТА АКТУАЛЬНІ ПРОБЛЕМИ ОПОДАТКУВАННЯ

СУБ'ЄКТІВ МАЛОГО ПІДПРИЄМНИЦТВА

О. М. Корчик

ПРОБЛЕМА ПРАВОВОГО РЕГУЛЮВАННЯ КРИПТОВАЛЮТ

В УКРАЇНI

O. I. Кузьмак

ТЕНДЕНЦІЇ ТА ПЕРСПЕКТИВИ МАРКЕТИНГУ ФІНАНСОВИХ ПОСЛУГ В УМОВАХ РОЗВИТКУ ЦИФРОВИХ ТЕХНОЛОГІЙ

С. О. Левицька

ТРАНСФЕРТНЕ ЦІНОУТВОРЕННЯ ЯК ВАЖЛИВИЙ ІНСТРУМЕНТ ОПТИМІЗАЦІЇ ЕКОНОМІЧНОЇ ВИГОДИ ВІД ВИКОРИСТАННЯ ВИРОБНИЧИХ РЕСУРСІВ

Н. А. Мамонтова, М. В. Вавілов

ВПЛИВ ПАНДЕМІЇ НА ФІНАНСИ СУБ'ЄКТІВ ТУРИСТИЧНОЇ ГАЛУЗІ

О. В. Маркус, Т. О. Шматковська

ОБГРУНТУВАННЯ НЕОБХІДНОСТІ ІНТЕГРАЦІЇ ФІНАНСОВОЇ

TA ESG-3ВITHOCTI В УМОВАХ СТАЛОГО РОЗВИТКУ

М. П. Мікула

ТЕНДЕНЦІЇ РОЗВИТКУ ТА ВИКОРИСТАННЯ СУБД 98

С. В. Мовчун

ДО ПИТАННЯ ВИКОРИСТАННЯ НЕПРЯМИХ МЕТОДІВ

КОНТРОЛЮ В ІТАЛІЇ: ХАРАКТЕРИСТИКА

ТА ЗАПРОВАДЖЕННЯ 


\section{А. Ф. Новак}

ТЕОРЕТИКО-МЕТОДИЧНІ ПІДХОДИ ЩОДО ФОРМУВАННЯ

СТРАТЕГІЇ ПОЗИЦЮЮВАННЯ ЗВО УКРАЇНИ 107

С. В. Ониико

РОЗВИТОК ФІНАНСОВОГО РИНКУ В УМОВАХ ЦИФРОВІЗАЦІЇ .......110

Т. С. Павлючук

МІСЦЕВИЙ БЮДЖЕТ: ЙОГО СУТНІСТЬ ТА ТЕРИТОРІАЛЬНИЙ БРЕНДИНГ ЯК ІНСТРУМЕНТ МІСЦЕВОГО РОЗВИТКУ

\section{I. М. Парасій-Вергуненко}

РОЛЬ ФІНАНСОВОГО ПЛАНУВАННЯ В УПРАВЛІННІ ДЕРЖАВНИМИ ПІДПРИЄМСТВАМИ

O. В. Повх

ОСОБЛИВОСТІ ВПРОВАДЖЕННЯ ЦИФРОВИХ ТЕХНОЛОГІЙ

В МАРКЕТИНГОВУ ДІЯЛЬНІСТЬ ПІДПРИЄМСТВА

Я. А. Полюхович

ПЕРСПЕКТИВИ РОЗВИТКУ КОРПОРАТИВНОГО БОРГУ В УКРАЇНI

C. Т. Пухир

СИСТЕМАТИЗАЦІЯ СУЧАСНИХ ФІНАНСОВИХ МЕХАНІЗМІВ РЕАЛІЗАЦІЇ ДЕРЖАВНОЇ РЕГІОНАЛЬНОЇ ПОЛІТИКИ В УКРАЇНI

Н. О. Рязанова

ФІНАНСОВИЙ МЕНЕДЖМЕНТ У БЮДЖЕТНОМУ ПРОЦЕСІ: ЗАРУБІЖНИЙ ДОСВІД

Г. В. Салата

ІННОВАЦІЙНІ МЕХАНІЗМИ РОЗВИТКУ БІБЛІОТЕК: ТЕХНОЛОГІЯ

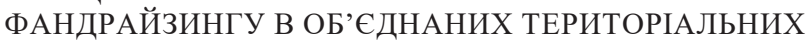
ГРОМАДАХ

О. О. Сельвеструк

ВІЛЬНА ТОРГІВЛЯ ЯК ОСНОВНИЙ ЕЛЕМЕНТ ЕКОНОМІЧНОЇ СВОБОДИ КРАЇНИ

B. С. Ташук

СИСТЕМАТИЗАЦІЯ МЕТОДІВ УПРАВЛІННЯ ФІНАНСОВИМИ РЕСУРСАМИ ПІДПРИЕМСТВА

О. Л. Тоцька

ФІНАНСОВІ ІННОВАЦІЇ У СВІТІ: ОГЛЯД ІННОВАЦІЙНИХ ПРОДУКТІВ ПЕРЕМОЖЦІВ ВАI GLOBAL INNOVATION AWARDS 2020

Ю. Ю. Харчук

КОНКУРЕНТОСПРОМОЖНІСТЬ ЗВО НА РИНКУ ОСВІТНІХ ПОСЛУГ УКРАЇНИ У КОНТЕКСТІ РИЗИК-МЕНЕДЖМЕНТУ ТА ЯКІСНОГО ОБЛІКОВО-АНАЛІТИЧНОГО ЗАБЕЗПЕЧЕННЯ ЇХНЬОЇ ДІяЛЬНОСТІ 


\section{I. І. Чуницька, А. С. Ясентюк}

СУЧАСНІ ТЕНДЕНЦІЇ РОЗВИТКУ РИНКУ СТРАХОВИХ ПОСЛУГ ....162

T. О. Шматковська, Р. І. Содома, О. В. Маркус

БІЗНЕС-МОДЕЛЮВАННЯ ФРАНЧАЙЗИНГУ В СИСТЕМІ СТАЛОГО РОЗВИТКУ В УКРАЇНІ

ю. В. Шулик

ЗАСТОСУВАННЯ ПРОЄКТНОГО ФІНАНСУВАННЯ ДЛЯ РОЗВИТКУ ОТГ В УКРАЇНІ

С. В. Юдіна, Ф. М. Жюдіт

РОЗВИТОК МЕТОДОЛОГІЧНИХ ТА МЕТОДИЧНИХ ОСНОВ ОПОДАТКУВАННЯ

Я. М. Юхимчук

СУЧАСНИЙ СТАН ТА ТЕНДЕНЦІЇ РОЗВИТКУ МАЛОГО І СЕРЕДНЬОГО ПІДПРИЄМНИЦТВА В УКРАЇНІ

О. С. Явдоико

ВПЛИВ КРЕДИТІВ МІЖНАРОДНИХ ФІНАНСОВИХ ОРГАНІЗАЦІЙ НА ЕКОНОМІЧНИЙ РОЗВИТОК УКРАЇНИ

А. І. Янюк

ПРИБУТОК ПІДПРИЕМСТВА: ЙОГО ФОРМУВАННЯ В УМОВАХ РИНКОВОЇ ЕКОНОМІКИ 